\title{
Reminiscences of Ittapana, 1963-65
}

Many a time I have been reminiscing about Ittapana. Every time I do so, I feel happy. So I thought of writing about it. I was a District Medical Officer (DMO), Ittapana from April 1963 to April 1965. It was my first appointment after internship. I went on a reconnaissance before assuming duties. Ittapana was a poor village. There was a 50-bed hospital. The DMO's quarters was in the premises. I met an Assistant Medical Practitioner (AMP). He discouraged me. He told me, "Doctor why do you want to come to this dry place"?

When the day came, one of my dear departed friends who had married a lady from Ittapana took me to my new station. I had nothing much to carry. All I took was a bed, a table, two chairs, and an old drawing room suite. I did not even have a radio.

The hospital had three buildings. One had a male ward, a female ward (which also took children), a small office room, and a drug store. The maternity ward and dispensary were in separate buildings.

There were two AMPs, three midwives, attendants, and labourers. There were no nurses.

The AMPs did not have quarters. One lived near the hospital. The other lived further away. From 5.00 p.m. till 8.00 a.m., when a patient came for admission, or when a patient in the hospital needed attention, a labourer had to call the AMP. There was a delay in attending to patients even when I was in my quarters. I changed the procedure. I told them that when I am in the quarters I can be called directly. Initially the AMPs did not like it. They thought that I was trying to make money. Except for every other weekend I was in the quarters. I handed over my quarters to an AMP whenever I left station.

I had no vehicle. Although the Department of Health wanted me to buy a car I could not afford one. I had 
commitments which took away more than half my salary of Rs 630.

Because of the shortage of doctors there was no Medical Officer of Health (MOH) in my area. The Agalawatte $\mathrm{MOH}$ office was in charge of a senior public health inspector. Hence my duties included conducting ante-natal and child welfare clinics near my hospital. I had to travel four days a week for these. The fifth day was to attend courts at Matugama. It was not possible to go to these places by bus.

I was in a pensive mood when a relative of mine living in Ittapana visited me. He asked me what my problem was and I told him. In a few days he came up with a solution. He found a car which could take me wherever I wanted, whenever I wanted. I had to pay the owner-driver 40 cents a mile. The government paid me only 25 cents a mile ( hired car rate). For every mile I travelled on official work I lost 15 cents. But I was happy because I was able to do my work.

I did a ward round in morning, afternoon and night. I also saw out-patients. The two AMPs were good workers. One is now having a good private practice in the deep south. The news of good patient care spread quickly. Numbers in the indoor and outdoor increased. The hospital which had an average bed occupancy of 10 when I took over was now having floor patients.

We were now running short of drugs. I went with a supplementary estimate to Dr. FC Spittel, the genial Superintendent of Health Services (SHS), Kalutara. Though he had not visited Ittapana, he knew what was going on. He readily approved the estimate. Then I went to Colombo to meet Mr. DAA Munasinghe, the Superintendent of the Civil Medical Stores. He looked at the estimate and told me, "Doctor, you must be having a good practice." I told him that nobody in Ittapana hospital does private practice and described to him how we managed the hospital. He looked me in the eye and said, "I believe you". He said that he will send the drugs. From then on there was no problem about drugs. My supplementary requests were honoured.

The local member of parliament (MP) was from the government party. His supporters were becoming a nuisance. They were in and out of the hospital at any time they wanted. The hospital staff were scared of them. One evening I asked them to get out of the hospital. I told them that they could come only during visiting hours. They were very angry. They told me that they will teach me a lesson.

A few weeks later when I happened to meet the SHS, he asked me why I threw out the MP's supporters. The MP had sent a petition against me to the Minister. It had come down the normal channels for my report. I told him the story. He supported me. The MP also did not proceed further because he found that Ittapana Hospital was functioning well.

The AMPs were now good friends of mine. We had regular contract bridge sessions at my quarters. There were a number of government surveyors in Ittapana. They had taught us bridge. The sessions were generally from 5.30 p.m. to 8.30 p.m. - till the last bus. Occasionally, we went on till late. If we passed midnight I had to ask the man who ran the generator of the Department of Electrical Undertakings to keep the electricity going. The hospital and the quarters had electricity only from 6.00 p.m. to midnight.

On one occasion there were floods. The hospital, which was on the higher ground, became an island. We were marooned for a week. For one week the diet contractor gave us only rice and dhal.

I did medico-legal work for the Welipenna Police area. I had a good relationship with the Police. Occasionally they brought convicts for medical examination. Once the Police had broken a man's tooth. The Officer-in-Charge said "Doctor, isn't it simple hurt?" I posted the Police Ticket saying, grievous hurt - fracture tooth. Afterwards the Police avoided me.

DMOs were not allowed private practice. Although some practised, I did not. The Government Medical Officers' Association went on demanding the right of private practice. Practice was granted to medical officers in charge of Stations, where a qualified medical officer in full time private practice was not available within a radius of three miles. So I was eligible for private practice. I gave notice that I will see patients after working hours. The approved fee was Rs 15, Rs 5 for the government and Rs 10 to me. In the first month the nearby Ayurvedic doctor sent me two patients. I remitted Rs 10 to the SHS. I got a call from the Accountant at the Office of the SHS. He said, "Doctor you are the only one doing private practice in the Kalutara district!" In fact I was the only one who had sent the mandatory Rs 5 per patient to the SHS!

Next month I went to do a post-mortem. I was walking along a foot path with the labourer (who would cut up the body). I was accosted by a man who insisted that I drink some young coconut water from him. I went with him to his hut. It had only a bed and no chairs. This was the man who had 'channelled' me to see his infant son with cyanotic heart disease. I was ashamed that I had taken Rs 15 from him. I handed over his money and decided not to do private practice.

Ittapana had two telephones. The Post Office was Ittapana 1. The hospital was Ittapana 2. But the telephones rarely worked. I had no ambulance. The theory was that I could get an ambulance from Kalutara or Pimbura hospitals (each about 20 miles away). Most of the time the telephone did not work, nor an ambulance was available. I had to transfer patients by a hired car. I had to pay first. The SHS office took time to reimburse me. The transfers were mostly obstructed labour and post-partum haemorrhage. Sometimes I went with the patient to Kalutara hospital.

I removed retained placentas under pethidine. In addition, an AMP administered chloroform through a mask. The rubber gloves were boiled and reused. Penicillin and 
streptomycin were the treatment for infections. We had few syringes and needles. They were put into the steriliser with boiling water and used over and over again.

Although I was happy at work, I continuously applied for a transfer. I wanted to be in a big hospital so that I did not have to manage a house. At the end of 2 years I got a special appointment. I received a message asking me to meet Dr. CHSP Jayasuriya in Head Office. When I went he roared at me. He said, "You ask for a transfer and then get people to send petitions to keep you. If you want you can stay, but I will not move you out till you complete four years." He told me that a petition had been sent to the new Minister of Health that I should not be transferred. The organiser had been the Chairman, Village Council, Welipenna, a party man of the new government. I told Dr. Jayasuriya, "Sir, I have asked for a transfer. I want to leave Ittapana".

Lucian Jayasuriya, Medical Advisor, GlaxoSmithKline, Sri Lanka. E-mail <lucian.b.jayasuriya@gsk.com>.

\section{From research to action - a bridge to be crossed}

John Snow's removal of the handle of the water pump on Broad Street, London, in order to contain an epidemic of cholera in 1854 was not only a classic in epidemiological method but also the application of an evidence-based public health intervention. Nevertheless, 150 years later, in much of the developing world the bridge between research and action still remains to be crossed. Research is necessary, good research is essential, but to translate knowledge generated by research into evidence-based actions is critical.

B Melgaard. From research to action - a bridge to be crossed. Bulletin of the World Health Organisation 2004; 82: 723. 